\title{
Dissolution of gall stones with an ursodeoxycholic acid menthol preparation: a controlled prospective double blind trial
}

\author{
M LEUSCHNER, U LEUSCHNER, D LAZAROVICI, W KURTZ, \\ AND A HELLSTERN \\ From the Zentrum der Inneren Medizin der Johann Wolfgang Goethe-Universität, Frankfurt/Main, Federal \\ Republic of Germany
}

SUMMARY In a controlled prospective double blind trial patients with cholesterol gall bladder stones are treated with ursodeoxy-cholic acid (group A: UDCA $11 \cdot 1 \mathrm{mg} / \mathrm{kg}$ per day; $\mathrm{n=16}$ ) and Ursomenth respectively (group B: a mixture of UDCA/menthol: $4.75 \mathrm{mg} / \mathrm{kg}$ per day each; $\mathrm{n}=17$ ). With same stone number and size (10-12 mm) there is a complete dissolution rate in group $A$ of $38 \%$, and of $53 \%$ in group B within 15-16.9 months. The response rate (complete + partial dissolution) amounted to $75 \%$ and $76 \%$ respectively. In group $A$ there is one case of stone calcification, in group $B$ none. Both preparations are free of unwanted effects. This suggests that the cyclic monoterpene menthol enhances the effect of UDCA and is of comparable effect to a mixture of six different terpenes used in former times.

In 1979 Bell and Doran' reported the treatment of 24 patients with cholesterol stones of the gall bladder and the bile ducts with Rowachol ${ }^{(\mathrm{R}) *}$, one capsule/10 $\mathrm{kg} /$ day. After six to 12 months the stones had dissolved in four patients partially and in three patients completely. In $1981^{2}$ the same group reported on Rowachol treatment of 13 patients with bile duct stones. In eight of 13 patients the concrements had vanished. In 1984 the authors ${ }^{3}$ administered Rowachol (one capsule twice daily) plus $7 \cdot 0-10 \cdot 5 \mathrm{mg} / \mathrm{kg} /$ day chenodeoxycholic acid (CDCA) to 29 patients with gall stones. After two years the stones were completely dissolved in 15 patients. Finally in 1985 the same group ${ }^{4}$ reported on the treatment of 19 patients with common bile duct stones with Rowachol and 15 patients with the combination Rowachol and CDCA (CDCA: 3.8$16.6 \mathrm{mg} / \mathrm{kg} / \mathrm{day} ; \mathrm{n}=11$ ) or ursodeoxycholic acid (UDCA: $4 \cdot 5-7 \cdot 1 \mathrm{mg} / \mathrm{kg} /$ day; $\mathrm{n}=4$ ). In the first group eight of 19 , in the second group 11 of 15 patients

*Rowa Ltd, Bantry, Co Cork, Eire.

Address for correspondence: Prof $U$ Leuschner MD, Zentrum der Inneren Medizin der Johann Wolfgang Goethe-Universität, Theodor-Stern-Kai 7, 6000) Frankfurt/Main 70, FRG

Received for publication 17 November 1987 became stone free. Perhaps Rowachol may even dissolve calcified cholesterol stones. ${ }^{5}$

Rowachol is a mixture of six cyclic monoterpenes: menthol, menthone, pinene, borneol, camphene and cineol. ${ }^{6}$ From the first stone dissolution with Rowachol by Sarreither in 1955 (Sarreither W, Medizinische Monatsschrift 1955; 9.97 cited according to ref 6) until today all patients were treated either with this mixture alone or in combination with CDCA and only four patients with UDCA. None of the studies were undertaken in double blind form.

Therefore we carried out the following investigations that should elucidate three questions: (1) Can the cholelitholytic effect of terpenes be corroborated in a controlled prospective double blind study? (2) Is the combination of menthol with UDCA as effective as the combination of six terpenes with CDCA? (3) Is the mixture of six terpenes necessary or will the use of menthol do?

\section{STUDY DESIGN}

The study was done as a controlled prospective double-blind trial for 24 months. Forty patients with symptomatic radiolucent gall stones were admitted in two groups of 20 patients each. Patient selection was done by sonography, plain gall bladder radiograph 
Table 1 Data on all patients allocated to group A (UDCA)

\begin{tabular}{|c|c|c|c|c|c|c|c|}
\hline \multirow[b]{2}{*}{$n$} & \multirow[b]{2}{*}{ Sex } & \multirow[b]{2}{*}{$\begin{array}{l}\text { Age } \\
\text { (years) }\end{array}$} & \multirow[b]{2}{*}{$\begin{array}{l}\text { Height } \\
(\mathrm{cm})\end{array}$} & \multirow[b]{2}{*}{$\begin{array}{l}\text { Weight } \\
(\mathrm{kg})\end{array}$} & \multirow[b]{2}{*}{$\begin{array}{l}\text { Overweight } \\
\text { (De Broca) }\end{array}$} & \multicolumn{2}{|c|}{ Stones } \\
\hline & & & & & & $n$ & $\begin{array}{l}\text { Size of } \\
\text { the biggest } \\
\text { stone }(\mathrm{mm})\end{array}$ \\
\hline 1 & F & 61 & 158 & 63 & $27 \cdot 8 \%$ & 1 & 8 \\
\hline 2 & $\mathrm{~F}$ & 73 & 154 & 85 & $85 \cdot 2 \%$ & 20 & 6 \\
\hline 3 & F & 53 & 170) & 70) & $17 \cdot 6 \%$ & 1 & 15 \\
\hline 4 & $\mathbf{F}$ & 62 & 170 & 73 & $22 \cdot 7 \%$ & 2 & 15 \\
\hline 6 & $\mathrm{~F}$ & 74 & 162 & 67 & $27 \cdot 1 \%$ & 10 & 11 \\
\hline 8 & $\mathrm{~F}$ & 35 & 156 & 65 & $36 \cdot 5 \%$ & 2 & 7 \\
\hline 10 & $\mathrm{~F}$ & 45 & 170 & 65 & $9 \cdot 2 \%$ & 2 & 15 \\
\hline 12 & $\mathrm{~F}$ & 59 & $160)$ & 68 & $33 \cdot 3 \%$ & 10) & 5 \\
\hline 13 & $\mathrm{~F}$ & 77 & 157 & 64 & $31.9 \%$ & 15 & 10 \\
\hline 14 & M & 60) & 172 & 85 & $31 \cdot 2 \%$ & 3 & 6 \\
\hline 15 & M & 55 & 179 & 85 & $19 \cdot 5 \%$ & 1 & 12 \\
\hline 18 & $\mathrm{~F}$ & 31 & 164 & 120 & $120 \cdot 6 \%$ & 3 & 15 \\
\hline 20) & M & 67 & 172 & 75 & $15 \cdot 7 \%$ & 1 & 5 \\
\hline 21 & $F$ & 31 & 168 & 74 & $17 \cdot 6 \%$ & 1 & 15 \\
\hline 22 & $\mathrm{~F}$ & 29 & 174 & 119 & $89 \cdot 2 \%$ & 3 & 15 \\
\hline 29 & $\mathrm{~F}$ & 34 & 183 & 73 & $3 \cdot 5 \%$ & 10 & 5 \\
\hline 31 & $F$ & 46 & 158 & 78 & $58 \cdot 2 \%$ & 6 & 15 \\
\hline 33 & M & 38 & 168 & 75 & $22 \cdot 5 \%$ & 8 & 7 \\
\hline 35 & $\mathrm{~F}$ & 50 & 172 & 63 & $2.9 \%$ & 1 & 6 \\
\hline 39 & M & 52 & 185 & 105 & $37 \cdot 2 \%$ & 6 & 7 \\
\hline Mean & $\begin{array}{l}F: 15 \\
M: 5\end{array}$ & $51 \cdot 6$ & $167 \cdot 6$ & $78 \cdot 6$ & $35 \cdot 47 \%$ & $5 \cdot 3$ & $10 \cdot 0$ \\
\hline
\end{tabular}

and oral or intravenous cholecystography. The patients' allocation to group $\mathrm{A}$ and $\mathrm{B}$ and the assessment of the results were done by the Institut für Medizinische Datenverarbeitung, Grebenhain, FRG. The study was approved by our local ethics committee. All patients gave written consent to participation. Sex, age, size, weight, and stone number of groups $\mathrm{A}$ and $\mathrm{B}$ are given in Tables 1 and 2 .

Group A received UDCA as monotherapy. Group $B$ received Ursomenth, a combination of $100 \mathrm{mg}$ UDCA and $100 \mathrm{mg}$ menthol in one capsule. Both UDCA and menthol are registered in the German AMG (AMG 76); their purity corresponded to the requirements of the DAB $8 \dagger$. Ursomenth was packed in gastric juice resistant soft gelantinous capsules (Scherer, FRG). All preparations were provided by the company Steiner \& Co, Deutsche Arzneimittelgesellschaft, Berlin, FRG.

Patients weighing less than $50 \mathrm{~kg}$ received two capsules UDCA of $250 \mathrm{mg}$ or Ursomenth at bedtime. From 50-75 kg we gave one capsule at noon, two capsules at bedtime. In cases of $75-100 \mathrm{~kg}$ body weight we gave one capsule at noon and three capsules at bedtime. Cases of $100-125 \mathrm{~kg}$ received one capsule at noon and four at bedtime. The mean UDCA dosage amounted to $11.1 \mathrm{mg} / \mathrm{kg}$ per day; the

†Neither the Ames test nor the DNA repair test (National Cancer Institute. USA) gave any indication of carcinogenic effect.
Table 2 Data on all patients allocated to group B (Ursomenth)

\begin{tabular}{|c|c|c|c|c|c|c|c|}
\hline \multirow[b]{2}{*}{$n$} & \multirow[b]{2}{*}{ Sex } & \multirow[b]{2}{*}{$\begin{array}{l}\text { Age } \\
\text { (years) }\end{array}$} & \multirow[b]{2}{*}{$\begin{array}{l}\text { Height } \\
(\mathrm{cm})\end{array}$} & \multirow[b]{2}{*}{$\begin{array}{l}\text { Weight } \\
(k g)\end{array}$} & \multirow[b]{2}{*}{$\begin{array}{l}\text { Overweight } \\
\text { (De Broca) }\end{array}$} & \multicolumn{2}{|c|}{ Stones } \\
\hline & & & & & & $n$ & $\begin{array}{l}\text { Size of } \\
\text { the biggest } \\
\text { stone }(\mathrm{mm})\end{array}$ \\
\hline 5 & $\mathbf{F}$ & 45 & 160 & 77 & $51 \%$ & 4 & 15 \\
\hline 7 & $\mathrm{~F}$ & 48 & 162 & 55 & $1 \cdot 5 \%$ & 6 & 8 \\
\hline 9 & $\mathrm{~F}$ & 45 & 161 & 70 & $34.8 \%$ & 2 & 9 \\
\hline 11 & $\mathrm{~F}$ & 40 & 153 & 58 & $28.7 \%$ & 5 & 14 \\
\hline 16 & $\mathrm{~F}$ & 69 & 153 & 74 & $64 \cdot 3 \%$ & 10 & 12 \\
\hline 17 & $\mathrm{~F}$ & 42 & 170 & 66 & $10 \cdot 9 \%$ & 8 & 13 \\
\hline 19 & $F$ & 17 & 164 & 60 & $10 \cdot 3 \%$ & 10 & 10 \\
\hline 23 & $\mathrm{~F}$ & 62 & 163 & 69 & $8 \cdot 7 \%$ & 8 & 14 \\
\hline 24 & $\mathbf{M}$ & 40 & 166 & 78 & $31 \cdot 3 \%$ & 2 & 7 \\
\hline 25 & $\mathbf{F}$ & 34 & 160 & 65 & $27 \cdot 4 \%$ & 1 & 13 \\
\hline 26 & $\mathrm{M}$ & 57 & 172 & 100 & $54 \cdot 3 \%$ & 1 & 15 \\
\hline 27 & $F$ & 33 & 160 & 70 & $37 \cdot 2 \%$ & 10 & 6 \\
\hline 28 & $F$ & 36 & 154 & 90 & $96 \cdot 01 \%$ & 7 & 15 \\
\hline 30 & $\mathbf{M}$ & 63 & 172 & 85 & $31 \cdot 2 \%$ & 5 & 8 \\
\hline 32 & $\mathrm{~F}$ & 63 & 172 & 78 & $27 \cdot 4 \%$ & 2 & 10 \\
\hline 34 & $\mathrm{~F}$ & 61 & 168 & 60 & $3.8 \%$ & 10 & 6 \\
\hline 36 & $\mathrm{~F}$ & 52 & 150 & 63 & $48 \cdot 2 \%$ & 2 & 8 \\
\hline 37 & $\mathrm{~F}$ & 51 & 170 & 61 & $2 \cdot 5 \%$ & 7 & 8 \\
\hline 38 & $F$ & 38 & 166 & 64 & $14 \cdot 1 \%$ & 1 & 9 \\
\hline 40 & $\mathrm{~F}$ & 55 & 152 & 62 & 4()$\cdot 3 \%$ & 2 & 13 \\
\hline Mean & $\begin{array}{l}F: 17 \\
M: 3\end{array}$ & $47 \cdot 6$ & $162 \cdot 4$ & $70 \cdot 3$ & $31 \cdot 2 \%$ & $5 \cdot 1$ & $10 \cdot 7$ \\
\hline
\end{tabular}

mean Ursomenth dosage was $9.6 \mathrm{mg} / \mathrm{kg}$ per day. This corresponds to $4.8 \mathrm{mg}$ UDCA $+4.8 \mathrm{mg}$ menthol $/ \mathrm{kg}$ per day. Only complete and not partial dissolution was considered as therapeutic success.

The patients were first examined by sonography, radiology, and laboratory tests (BSR, WBC, RBC, SGOT, SGPT, GGT, AP, bilirubin, albumin, total protein, BUN, creatinine, triglycerides, cholesterol, uric acid, potassium, calcium, sodium, chloride, fasting glucose). Follow up: every six months ultrasound sonography of upper abdomen, every two months the aforementioned laboratory tests were done.

\section{Results}

In group A four patients dropped out, in group B three dropped out which meant that seven patients wished to leave the study without any contraindications. Hence 33 patients fulfilled all the study requirements (group A: 16; group B: 17) and were treated.

Group A (treated patients) comprised four men and 12 women. Group B comprised two men and 15 women. The mean age of group A was $48 \cdot 8$ years and of group B 48.6 years. The mean body weight of group A was $79.7 \mathrm{~kg}$ and of group B $68.5 \mathrm{~kg}$. The mean stone number of group A was 4.2 and of group $B$ 4.7. The mean stone size in group $A$ was $9.6 \mathrm{~mm}$ 
Table 3 Results of UDCA treatment (group $A ; n=16$ )

\begin{tabular}{llll}
\hline$n$ & $\begin{array}{l}\text { UDCA } \\
(m g / k g / \text { day })\end{array}$ & $\begin{array}{l}\text { Stones } \\
(n / m m)\end{array}$ & $\begin{array}{l}\text { Dissolution time } \\
\text { (months) }\end{array}$ \\
\hline 4 & $10 \cdot 3$ & $2 / 15$ & 24 \\
14 & $11 \cdot 8$ & $3 / 6$ & 6 \\
20 & $10 \cdot 0$ & $1 / 5$ & 18 \\
22 & $10 \cdot 5$ & $3 / 15$ & 24 \\
29 & $10 \cdot 3$ & $10 / 5$ & 6 \\
35 & $11 \cdot 9$ & $1 / 6$ & 12 \\
Mean & $10 \cdot 8$ & $3 \cdot 3 / 8 \cdot 7$ & $15 \cdot()$ \\
1 & $11 \cdot 9$ & $1 / 8$ & Partial dissolution \\
6 & $11 \cdot 2$ & $10 / 11$ & Partial dissolution \\
8 & $11 \cdot 5$ & $2 / 7$ & 1 calcification, \\
& & & 1 dissolved \\
10 & $11 \cdot 5$ & $2 / 15$ & Partial dissolution \\
12 & $11 \cdot 5$ & $10 / 5$ & - \\
18 & $10 \cdot 4$ & $3 / 15$ & - \\
21 & $10 \cdot 1$ & $1 / 15$ & Partial dissolution \\
31 & $12 \cdot 8$ & $3 / 15$ & Partial dissolution \\
33 & $10 \cdot 0$ & $8 / 7$ & - \\
39 & $11 \cdot 9$ & $6 / 7$ & - \\
Mean & $11 \cdot 3$ & $4 \cdot 6 / 10 \cdot 5$ & \\
\hline
\end{tabular}

Mean UDCA dosage: $11.1 \mathrm{mg} / \mathrm{kg} /$ day; complete dissolution: $6 / 16$ (38\%); partial dissolution: $6 / 16(37 \%)$; response rate: $75 \%$; mean treatment time until dissolution: $15 \cdot()$ months.

and in group B $10.5 \mathrm{~mm}$. Thus groups A and B were well matched (Tables 1 and 2).

In group A stones dissolved completely in six of 16 patients $(37.5 \%)$ and partially in another six of 16 $(37.5 \%)$. In group B there was complete dissolution in nine of 17 patients $(53 \%)$ and partial dissolution in four of $17(23 \%)$. This difference is statistically not significant. One patient from group B had to be withdrawn in the 18th month of treatment because of colic. He was considered as a non-responder. In group A UDCA responders had approximately the same stone number as non-responders but stones of the non-responders were some $2 \mathrm{~mm}$ larger than those of the responders. In group B stone number was the same in responders and non-responders too but the stone size of non-responders was larger (Tables 3 and 4). When groups $A$ and B are compared with respect to the stones dissolved, in the Ursomenth group we dissolved rather more and larger stones than in the UDCA group. In group A one patient experienced stone calcification after one of his two stones had completely dissolved. In group $B$ there was no stone calcification. The mean treatment time amounted to 15 months in group $\mathrm{A}$ and 16.9 months in group B. The differences between stone size and number and dissolution time are not significant in groups $\mathrm{A}$ and $\mathrm{B}$. That means that Ursomenth had dissolved the same number and equally large stones in the same time as UDCA. Complete and partial dissolution, individual UDCA/ menthol dosage and treatment time are given in Tables 3 and 4 .
Table 4 Results of ursomenth treatment (group $B ; n=17$ )

\begin{tabular}{llll}
\hline & $\begin{array}{l}\text { Ursomenth } \\
\text { UDCA/menthol: } \\
\text { mg/kg/day) }\end{array}$ & $\begin{array}{l}\text { Stones } \\
(n / m m)\end{array}$ & $\begin{array}{l}\text { Dissolution time } \\
\text { (months) }\end{array}$ \\
\hline 7 & 5.5 & $6 / 8$ & 6 \\
17 & $4 \cdot 5$ & $8 / 13$ & 24 \\
27 & $4 \cdot 3$ & $10 / 6$ & 24 \\
30 & $4 \cdot 7$ & $5 / 8$ & 20 \\
32 & $5 \cdot 1$ & $2 / 10$ & 24 \\
36 & $4 \cdot 8$ & $2 / 8$ & 8 \\
37 & $4 \cdot 9$ & $7 / 8$ & 14 \\
38 & $4 \cdot 7$ & $1 / 9$ & 8 \\
40 & $4 \cdot 8$ & $2 / 13$ & 24 \\
Mean & $4 \cdot 8 / 4 \cdot 8$ & $4 \cdot 8 / 9 \cdot 2$ & $16 \cdot 9$ \\
5 & $5 \cdot 2$ & $4 / 15$ & Partial dissolution \\
9 & $4 \cdot 3$ & $2 / 9$ & - \\
11 & $5 \cdot 2$ & $5 / 14$ & Partial dissolution \\
16 & $4 \cdot()$ & $10 / 12$ & - \\
23 & $4 \cdot 3$ & $8 / 14$ & Partial dissolution \\
24 & $5 \cdot 2$ & $2 / 7$ & - \\
25 & $4 \cdot 6$ & $1 / 13$ & Even resistant to \\
28 & $4 \cdot 7$ & $7 / 15$ & MTBE \\
& & & Withdrawal after \\
Mean & $4 \cdot 7 / 4 \cdot 7$ & $4 \cdot 9 / 12 \cdot 4$ & - \\
\hline
\end{tabular}

Mean UDCA $/$ menthol dosage: $4.8 \mathrm{mg} / \mathrm{kg} /$ day; complete dissolution: $9 / 17(53 \%)$; partial dissolution: $4 / 17(23 \%)$; response rate: $76 \%$; mean treatment time until dissolution: 16.9 months.

Both types of medication were free from unwanted effects. Laboratory tests were comparable in all groups. Apart from colic we noticed a rise in SGOT, SGPT, AP, or GGT of short duration. In almost all patients complaints decreased considerably and disappeared completely in the end. In group B one patient developed severe colic, he underwent surgery, and was classified as a non-responder.

\section{Discussion}

Ursomenth induced in $53 \%$ of those patients treated complete stone dissolution, UDCA in $38 \%$. When the percentage of partial stone dissolution is added which we did not consider as therapeutic success then the response rate in group A amounted to $75 \%$ and in group B to $76 \%$. In other words the result is almost identical for both types of medication. It is unlikely that the Ursomenth result can be ascribed to the UDCA portion in Ursomenth alone. This would mean that $4.8 \mathrm{mg} \mathrm{UDCA} / \mathrm{kg}$ per day corresponded to the $2 \cdot 3$-fold higher dosage of $11 \mathrm{mg} \mathrm{UDCA} / \mathrm{kg} / \mathrm{day}$. The Franco-Belgian study group ${ }^{7 \times}$ has shown, however, that already a UDCA dosage of $8.4 \mathrm{mg} / \mathrm{kg} / \mathrm{day}$ can significantly improve the dissolution rate compared with the half dosage of $4 \cdot 2 \mathrm{mg} / \mathrm{kg} / \mathrm{day}$. $^{7}$ This is in keeping with results of Dowling et al ${ }^{4}$ who showed in 55 responders that the optimal dosage is $9 \cdot 6$ 
Table 5 Studies showing dose dependency of gall stone dissolution with UDCA

\begin{tabular}{|c|c|c|c|c|}
\hline Reference & $\begin{array}{l}\text { Patients } \\
(n)\end{array}$ & $\begin{array}{l}\text { Stonesize } \\
(\mathrm{mm})\end{array}$ & $\begin{array}{l}\text { UDCA dose } \\
\text { (mg/kg/day) }\end{array}$ & $\begin{array}{l}\text { Complete } \\
\text { dissolution } \\
(\%)\end{array}$ \\
\hline \multirow[t]{2}{*}{ Salen et al $(1980)^{11}$} & 10 & $<15$ & $3 \cdot 6$ & 10) \\
\hline & 10 & $<15$ & $14 \cdot 3$ & 60 \\
\hline \multirow{8}{*}{$\begin{array}{l}\text { Tokyo Coop. Study } \\
\text { Group }(1980)^{11}\end{array}$} & 23 & $<5$ to $>15$ & $2 \cdot 7$ & $8 \cdot 7$ \\
\hline & 29 & $<5$ to $>15$ & $10 \cdot 5$ & $24 \cdot 1$ \\
\hline & 5 & $<5$ & $2 \cdot 7$ & $40 \cdot()$ \\
\hline & 7 & $<5$ & $10 \cdot 5$ & $71 \cdot 4$ \\
\hline & 9 & $5-15$ & $2 \cdot 7$ & $0 \cdot 0$ \\
\hline & 16 & $5-15$ & $10 \cdot 5$ & $12 \cdot 5$ \\
\hline & 7 & Floating & $2 \cdot 7$ & $28 \cdot 6$ \\
\hline & 6 & Floating & $10 \cdot 5$ & $50 \cdot 0$ \\
\hline \multirow{2}{*}{$\begin{array}{l}\text { Inter-Hospital } \\
\text { Clinical Research } \\
\text { Group }(1981)^{12}\end{array}$} & 36 & $<15$ & $5-6$ & 13.9 \\
\hline & 42 & $<15$ & $10-12$ & $28 \cdot 6$ \\
\hline \multirow[t]{3}{*}{ Podda et al (1982) } & 24 & $<20$ & $4 \cdot 0$ & $8 \cdot 3$ \\
\hline & 24 & $<20$ & $8 \cdot 0$ & $12 \cdot 5$ \\
\hline & 23 & $<20$ & $12 \cdot 0$ & $21 \cdot 7$ \\
\hline \multirow{4}{*}{$\begin{array}{l}\text { Franco-Bclgian } \\
\text { Study Group } \\
(1983)^{7}\end{array}$} & 34 & No data & $2 \cdot 1$ & $29 \cdot 4^{*}$ \\
\hline & 37 & & $4 \cdot 2$ & $37 \cdot 8^{*}$ \\
\hline & 38 & & $8 \cdot 4$ & $52 \cdot 5^{*}$ \\
\hline & 41 & . & $16 \cdot 3$ & $48 \cdot 8^{*}$ \\
\hline
\end{tabular}

${ }^{*}$ Complete plus partial dissolution.

$\mathrm{mg} / \mathrm{kg} /$ day and in 29 non-responders that a dosage of $7.2 \mathrm{mg} / \mathrm{kg} /$ day is already suboptimal. Other authors consider $8 \mathrm{mg} / \mathrm{kg} /$ day to be the optimal dosage; $74 \cdot 2$ $\mathrm{mg} / \mathrm{kg} /$ day are considered suboptimal. Further studies which confirm these results are given in Table $5 .^{11013}$ Because we procured the same or even better results with $4.8 \mathrm{mg}$ UDCA as with a $2 \cdot 3$-fold higher dosage, this suggests an enhancing effect of menthol.

In the UDCA group we observed stone calcification in one patient, none in the Ursomenth group. Unfortunately, to date we are not sure whether stone calcification under UDCA is dose dependent. ${ }^{1+}$ Should this be the case, then Ursomenth would represent a preparation preventing stone calcification. Investigations of Ellis et al ${ }^{\text {s }}$ would support this possibility where the terpene mixture of Rowachol even produced diminishing of calcified concrements. As Neuberg and Grauer ${ }^{15}$ showed in 1951, menthol secreted into bile in the form of glucuronide obviously improves the solubility of calcium carbonate and phosphate.

Our study suggests that terpenes have an adjuvant effect in stone dissolution with UDCA, that the effect of UDCA is comparable with that of $\mathrm{CDCA}^{3}$ in a combination preparation and that it is obviously not necessary to use a mixture of terpenes. The terpene menthol had the same effect as the Rowachol mixture.

The mode of action of terpenes has not been definitively clarified. In 1976 Kodama et al showed ${ }^{16}$ that the monoterpene d-limonene lowered the ratio bile acids and phospholipids to cholesterol in rats. In 1979 Doran et $^{1 l^{17}}$ reported that the terpene mixture Rowachol in a low dosage will lower the cholesterol concentration in bile but increase in high dosage. Finally in 1980 Clegg et a $^{1 \mathrm{x}}$ showed that the terpenes menthol and cineol inhibit HMG-CoA reductase by $70 \%$, borneol and menthone by $50 \%$ and that the terpenes pinene and camphene are without effect. As of the four effective terpenes in Rowachol cineol is present only in $2 \%$, borneol in $5 \%$, menthone in $6 \%$ but menthol in $32 \%$ concentration, ${ }^{6}$ the effect of Rowachol should be predominantly caused by menthol. This should explain why we have seen the same effect with Ursomenth as with Rowachol. Doran et $a l^{17}$ have reduced the cholesterol concentration with a total menthol dosage of $192 \mathrm{mg} / \mathrm{day}$. In a dosage of $512 \mathrm{mg} /$ day they noticed a rise. We administered $331 \mathrm{mg}$ menthol per day with Ursomenth and therefore we could speculate whether the amount of menthol in Ursomenth could not be reduced.

Furthermore, Rowachol has a choleretic effect and it is said to be a non-specific enzyme inducer. ${ }^{19}$ Igimi et al and ourselves ${ }^{2121}$ reported that the terpenes d-limonene and cineol would dissolve cholesterol stones in vitro too and thus the effect described by Clegg et al ${ }^{1 \times}$ for terpenes on HMG-CoA reductase is obviously not their only effect.

Whether the UDCA/menthol mixture will achieve an equally favourable dissolution rate in larger stones as UDCA monotherapy still has to be investigated in a considerably larger number of patients. The promising results discussed here in stones of an average of $10-12 \mathrm{~mm}$ suggest at least that UDCA/ menthol might be useful for recurrence prophylaxis. Stone recurrence after UDCA treatment is found in $20-50 \%=23$ and therefore a cheap preparation for longterm treatment is needed without unwanted effects.

\section{References}

1 Bell GD, Doran J. Gallstone dissolution in man using an essential oil preparation - Rowachol. Br Med J 1979; 1: 24.

2 Ellis WR, Bell GD. Treatment of biliary duct stones with a terpene preparation. Br Med J 1981; 282: 611 .

3 Ellis WR, Sommerville KW, Whitten BH, Bell GD. Pilot study of combination treatment for gallstones with medium dose chenodeoxycholic acid and a terpene preparation. Br Med J 1984; 289: 153-6.

4 Sommerville KW, Ellis WR, Whitten BH, Balfour TW, Bell GD. Stones in the common bile duct: experience with medical dissolution therapy. Postgrad Med J 1985; 61: 313-6.

5 Ellis WR, Rose DH, Richmond CR, Nehru AY, Middleton A, Bell GD. Radio-opaque gallstones reduction in size and calcium content on treatment with Rowachol [Abstract]. Gut 1980; 21: 910. 
6 Bell GD. Medical treatment of gallstones. $J R$ Coll Physns Lond 1979; 13: 1-6.

7 Erlinger S. Ursodeoxycholic and chenodeoxycholic acid treatment of radiolucent gallstones: follow-up report of a multicentric trial. In: Paumgartner G, Stiehl A, Gerok $\mathrm{W}$, eds. Bile acids and cholesterol in health and disease Lancaster: MTP Press, 1983: 365-6.

8 Erlinger S, Go AL, Hussen JM, Fevery J. FrancoBelgian cooperative study of ursodeoxycholic acid in the medical dissolution of gallstones: a double-blind randomised, dose-response study, and comparison with chenodeoxycholic acid. Hepatology 1984; 4: 308-14.

9 Dowling RH, Ruppin DC, Meredith T, Myszor M, Forgacs I, Murphy GM. Efficacy of bile acid treatment in dissolving gallstones: collateral benefits of CDCA and UDCA therapy; gallstone recurrence and postdissolution management. In: Paumgartner G, Stiehl A, Gerok $\mathrm{W}$, eds. Bile acids and cholesterol in health and disease. Lancaster: MTP Press, 1983: 345-62.

10 Salen G, Colalillo A, Verga D, Bagan E, Tint S, Shefer S. Effect of high and low doses of ursodeoxycholic acid on gallstone dissolution in humans. Gastroenterology 1980; 78: 1412-18.

11 Tokyo Cooperative Gallstone Study Group. Efficacy and indications of ursodeoxycholic acid treatment for dissolving gallstones. Gastroenterology 1980; 78: 542-8.

12 Inter-Hospital Clinical Research Group. Treatment of radiolucent gallstones with CDCA or UDCA: A multicentre trial. Digestion 1981; 22: 185-91.

13 Podda $M$, Zuin $M$, Carulli $N$, Ponz de Leon $M$, Dioguardi ML. Gallstone dissolution after 6 months of ursodeoxycholic acid (UDCA): effectiveness of different doses. J Int Med Res 1982; 10: 59-63.

14 Bouchier IAD, Neligan P. Calcification of radiolucent gallstones during ursodeoxycholic acid therapy. In:
Paumgartner G, Stiehl A, Gerok W, eds. Bile acids and cholesterol in health and disease. Lancaster: MTP Press, 1983: 397-8.

15 Neuberg C, Grauer A. Enzymologia 1951; 15: 115, cited according to ref 6 .

16 Kodama R, Inoue $\mathrm{H}$, Noda $\mathrm{K}$, Ide $\mathrm{H}$. Effect of dlimonene and related compounds on bile flow biliary lipid composition in rats and dogs. Life Sci 1976; 19: 1559-67.

17 Doran J, Keighley MRB, Bell GD. Rowachol - a possible treatment for cholesterol gallstones. Gut 1979; 20: 312-7.

18 Clegg RJ, Middleton B, Bell GD, White DA. Inhibition of hepatic cholesterol synthesis and S-3-hydroxy-3methylglutaryl-CoA reductase by mono- and bicyclic mono-terpenes administered in vivo. Biochem Pharmacol 1980; 29: 2125-7.

19 Ellis WR, Bell GD, Sommerville K, Clegg RJ, Middleton B, White DA. Mechanisms for adjuvant cholelitholytic properties of the monoterpene mixture Rowachol (R) [Abstract]. Clin Sci 1981; 61: 38.

20 Igimi $H$, Hisatsugu $T$, Nishimura $M$. The use of $d-$ limonene preparation as a dissolving agent of gallstones. Dig Dis 1976; 21 : 926-39.

21 Leuschner U, Rothe W, Klicic X, Frenk H. Methyl-tertbutyl ether (MTBE) treatment of cholesterol stones: toxicity and dissolution of stone debris [Abstract]. Gastroenterology 1987; 92: 1750.

22 Iser JH, Dowling RH, Mok HYI, Bell GD. Chenodeoxy-cholic acid treatment of gallstones - a follow-up report and analysis of factors influencing response to therapy. N Engl J Med 1975; 293: 378-83.

23 Ruppin DC, Dowling RH. Is recurrence inevitable after gallstone dissolution by bile acid treatment? Lancet 1982; i: 181-95. 